\title{
JPEB
}

Jurnal Penelitian Ekonomi dan Bisnis, 3(2), 2018, Hal: 73 - 83

http://www.jpeb.dinus.ac.id

\section{PENGARUH CITRA MEREK, KUALITAS PRODUK DAN HARGA TERHADAP KEPUTUSAN PEMBELIAN PRODUK MEREK EIGER (KAJIAN PADA MAHASISWA UNIVERSITAS MERCU BUANA YOGYAKARTA)}

\author{
Devi Puspita Sari dan Audita Nuvriasari \\ ${ }^{1,2}$ Program Studi Manajemen, Fakultas Ekonomi dan Bisnis, Universitas Mercu Buana \\ Jalan Wates Km. 10 Yogyakarta 55753, Indonesia \\ *Corresponding Email:devipuspitasari2102@gmail.com
}

Diterima: April 2018; Direvisi: Juli 2018; Dipublikasikan: September 2018

\section{ABSTRACT}

This research aims to know the influence of brand image, product quality and price on purchasing decisions of Eiger brand products. The sampling technique in this research used purposive sampling technique with a total sample of 100 respondents. Based on the results of the analysis of the t test it can be explained that the brand image, product quality and price have a positive and significant influence on the purchasing decisions of the Eiger brand products, where each independent variable (brand image, product quality and price) has a $t$ value of sig <0,05. Based on the results of the analysis of the F test, it can be explained that the brand image, product quality and price simultaneously have a positive and significant influence on the purchasing decisions of the Eiger brand products, where the $F$ sig value is 0,000 $<0,05$. Of the three independent variables, the most dominant variable influencing the purchasing decision of the Eiger brand is the product quality variable.

Keywords: Brand Image; Product Quality; Price; Purchasing Decision

\section{ABSTRAK}

Penelitian ini bertujuan untuk mengetahui pengaruh citra merek, kualitas produk dan harga terhadap keputusan pembelian produk merek Eiger. Teknik pengambilan sampel dalam penelitian ini menggunakan teknik purposive sampling dengan jumlah sampel sebanyak 100 responden. Berdasarkan hasil analisis dari uji t dapat dijelaskan bahwa citra merek, kualitas produk dan harga secara parsial berpengaruh positif dan signifikan terhadap keputusan pembelian produk merek Eiger, dimana masing-masing variabel independent (citra merek, kualitas produk dan harga) memiliki nilai t sig $<0,05$. Berdasarkan hasil analisis dari uji $\mathrm{F}$ dapat dijelaskan bahwa citra merek, kualitas produk dan harga secara simultan berpengaruh positif dan signifikan terhadap keputusan pembelian produk merek Eiger, dimana nilai $\mathrm{F}$ sig sebesar $0,000<0,05$. Dari ketiga variabel independent tersebut variabel yang paling dominan berpengaruh terhadap keputusan pembelian produk merek Eiger adalah variabel kualitas produk.

Kata Kunci : Citra Merek; Kualitas Produk; Harga; Keputuasan Pembelian 


\section{PENDAHULUAN}

Seiring dengan perkembangan ekonomi tingkat persaingan bisnis di bidang industri saat ini semakin lama semakin ketat khususnya untuk perusahaan-perusahan yang memproduksi produk yang sejenis. Oleh karena itu, keadaan ini mengakibatkan perusahaan harus dapat mengikuti perkembangan dan perubahan baik dibidang sosial maupun dibidang budaya. Mengikuti dan menganalisis strategi yang dilakukan oleh pesaing sangatlah penting untuk mengetahui sejauh mana bisnis pesaing sejenis melakukan perubahan dan perkembangan dalam bisnisnya, hal tersebut diharapkan mampu mendorong perusahan untuk meningkatkan produk-produk unggulannya serta meningkatkan kreativitas dan inovasi produk-produk yang ditawarkan kepada konsumen yang memiliki keunikan dan keunggulan sehingga produk tersebut mudah diingat dibenak konsumen dan dapat merebut pangsa pasar yang ada, karena dalam menentukan pilihan konsumen sangat mempertimbangkan hal-hal tersebut.

Perkembangan ekonomi juga sangat mempengaruhi gaya hidup masyarakat saat ini yang cenderung mengedepankan penampilan, yang mana penunjang penampilan tersebut di perlihatkan dengan cara penggunaan produk-produk yang telah memiliki kualitas dan dikenal oleh masyarakat. Gaya hidup yang demikian tidak hanya di perlihatkan oleh kalangan anak muda saja namun juga sudah mempengaruhi seluruh kalangan masyarakat. Hal tersebut mengakibatkan tingkat permintaan akan produk-produk yang diinginkan dan dibutuhkan oleh masyarakat meningkat. Citra merek merupakan salah satu faktor yang mempengaruhi dalam pengambilan keputusan konsumen, dengan faktor yang mempengaruhi antara lain asosiasi keunggulan, asosiasi kekuatan dan asosiasi keunikan (Keller, 2012). Dengan produk yang telah memiliki citra merek yang baik sudah pasti juga memiliki kualitas produk yang sesuai dengan harga yang ditawarkan oleh perusahaan kepada konsumen.

Citra merek pada dasarnya merupakan suatu hasil pandang atau persepsi konsumen terhadap suatu merek tertentu, yang didasarkan atas pertimbangan dan perbandingan dengan beberapa merek lainnya, pada jenis produk yang sama. Mengembangkan citra merek yang kuat merupakan cara untuk membuat konsumen mengenal produk sehingga citra merek tersebut dapat tertanam didalam pikiran konsumen serta mampu mempengaruhi perilaku konsumen dalam menentukan pilihan. Citra merek yang sudah tertanam di pikiran konsumen mampu menciptakan kepercayaan akan produk yang ditawarkan, kepercayaan yang diciptakan tersebut juga diiringi dengan kualitas produk yang diberikan oleh pihak perusahaan kepada konsumen sehingga mampu menimbulkan kepercayaan diri konsumen saat menggunakan produk tersebut.

Kualitas produk merupakan alat yang digunakan oleh perusahaan dalam menentukan positioning produk yang dipasarkan.Setiap perusahaan harus memilih tingkat kualitas produknya karena kualitas produk tersebut dapat membantu meningkatkan dan mempertahankan positioning produk dalam pasarnya. Kualitas produk juga berhubungan erat dengan nilai ekonomis suatu produk, yang mana nilai ekonomis ini menjadi pertimbangan konsumen dalam menentukan pilihan dan membandingkannya dengan produk lain yang sejenis.

Selain kualitas produk harga juga menjadi salah satu faktor yang paling menentukan keputusan akhir karena harga menjadi pertimbangan konsumen dalam memilih suatu produk. Sedangkan menurut Kotler dan Armstrong (2013), harga merupakan sejumlah uang yang dibebankan atas suatu barang atau jasa atau jumlah dari nilai uang yang ditukar konsumen atas manfaat-manfaat karena memiliki atau menggunakan produk atau jasa tersebut. Kesesuaian harga dengan kualitas produk harus seimbang agar produk-produk yang ditawarkan dapat diterima oleh konsumen.

Keputusan pembelian oleh konsumen adalah keputusan yang melibatkan persepsi terhadap kualitas, nilai dan harga. Saat ini citra merek, kualitas produk, harga merupakan faktor-fakor yang sangat berpengaruh terhadap keputusan pembelian produk dan kemudian akan menjadikan seseorang berubah konsumtif. Seperti saat ini banyak masyarakat yang 
memiliki hobi berpetualang, mendaki gunung dan melakukan aktivitas pencinta alam lainnya, dan Eiger merupakan salah satu perusahaan yang menyediakan penunjang kebutuhan bagi masyarakat yang memiliki hobi tersebut.Aktivitas-aktivitas tersebut mengakibatkan jumlah permintaan mengenai peralatan outdoor semakin meningkat. Perusahaan Eiger yang produknya sudah dikenal oleh masyarakat ini menawarkan produk-produk yang berkualitas dan harganya sesuai dengan kualitas diberikan.

Mengingat bahwa citra merek, kualitas produk dan harga merupakan faktor yang mempengaruhi keputusan pembelian, sehingga dilakukan penelitian yang berjudul "Pengaruh Citra Merek, Kualitas Produk dan Harga Terhadap Keputusan Pembelian Produk Merek Eiger (Kajian pada Mahasiswa Universitas Mercu Buana Yogyakarta)".

\section{TINJAUAN PUSTAKA \\ Perilaku Konsumen}

Perilaku konsumen merupakan suatu proses yang berkaitan erat dengan proses pembelian, pada saat itu konsumen melakukan aktifitas-aktifitas seperti melakukan pencarian, penelitian, dan pengevaluasian produk. Perilaku konsumen merupakan hal-hal yang mendasari konsumen untuk membuat keputusan pembelian. Menurut Hasan (2013) Perilaku konsumen adalah studi proses yang terlibat ketika individu atau kelompok memilih, membeli, menggunakan, atau mengatur produk, jasa, idea atau pengalaman untuk memuaskan kebutuhan dan keinginan konsumen.

\section{Keputusan Pembelian}

Menurut Sumarwan (2010) Keputusan pembelian adalah Bagaimana konsumen memutuskan alternatif pilihan yang akan dipilih, serta meliputi keputusan mengenai apa yang dibeli, apakah membeli atau tidak, kapan membeli, dimana membeli, dan bagaimana cara membayarnya. Menurut Kotler dan Armstrong (2008), ada empat faktor yang mempengaruhi perilaku konsumen dalam memutuskan melakukan pembelian, yaitu faktor budaya, faktor sosial, faktor pribadi, faktor psikologis. Menurut Kotler dan Amstrong (2014) ada lima tahapan dalam keputusan pembelian, yaitu need recognition (pengenalan masalah), information search (pencarian informasi), evaluation of alternatives (evaluasi alternatif), purchase decision (keputusan pembelian), postpurchase behavior (perilaku pasca pembelian).

\section{Citra Merek}

Menurut Kotler dan Keller (2009), citra merek adalah proses dimana seseorang memilih, mengorganisasikan, dan mengartikan masukan informasi untuk menciptakan suatu gambaran yang berarti. Menurut Aaker (2009) dalam Ananda (2010) faktor - faktor yang menjadi tolak ukur suatu brand image adalah product attributes (atribut produk), consumer benefits (keuntungan konsumen), brand personality (kepribadian merek).

\section{Kualitas Produk}

Menurut Kotler dan Amstrong (2008), menyebutkan bahwa kualitas adalah kemampuan produk untuk melaksanakan fungsi-fungsinya, kemampuan itu meliputi daya tahan, kehandalan, ketelitian yang dihasilkan, kemudahan dioperasikan dan diperbaiki dan atribut lain yang berharga pada produk secara keseluruhan. Menurut Tjiptono (2008), menyatakan bahwa ada 8 dimensi produk yang dapat digunakan untuk menganalisis karakteristik kualitas produk, yaitu kinerja (performance), keistimewaan tambahan (features), kesesuaian dengan spesifikasi (conformance to specification), keandalan (realibility), daya tahan (durability), estetika (easthetica), kualitas yang di presepsikan (perceived quality), dimensi kemudahan perbaikan (serviceability). 


\section{Harga}

Menurut Tjiptono (2008), menyatakan bahwa harga adalah sejumlah uang dan jasa atau barang-barang yang tersedia ditukarkan oleh pembeli untuk mendapatkan berbagai pilihan produkproduk dan jasa-jasa yang disediakan penjual. Menurut Kotler (2009) indikatorindikator harga yaitu keterjangkauan harga, kesesuaian harga dengan kualitas produk, daya saing harga, kesesuaian harga dengan manfaat.

\section{Kerangka Pikir}

Berdasarkan penyusunan tinjauan pustaka yang diajukan pada penelitian ini, maka dibuat model penelitian bahwa sikap yang dipengaruhi oleh variabel citra merek, kualitas produk, dan harga sehingga berimplikasi terhadap keputusan pembelian seperti pada model di bawah ini:

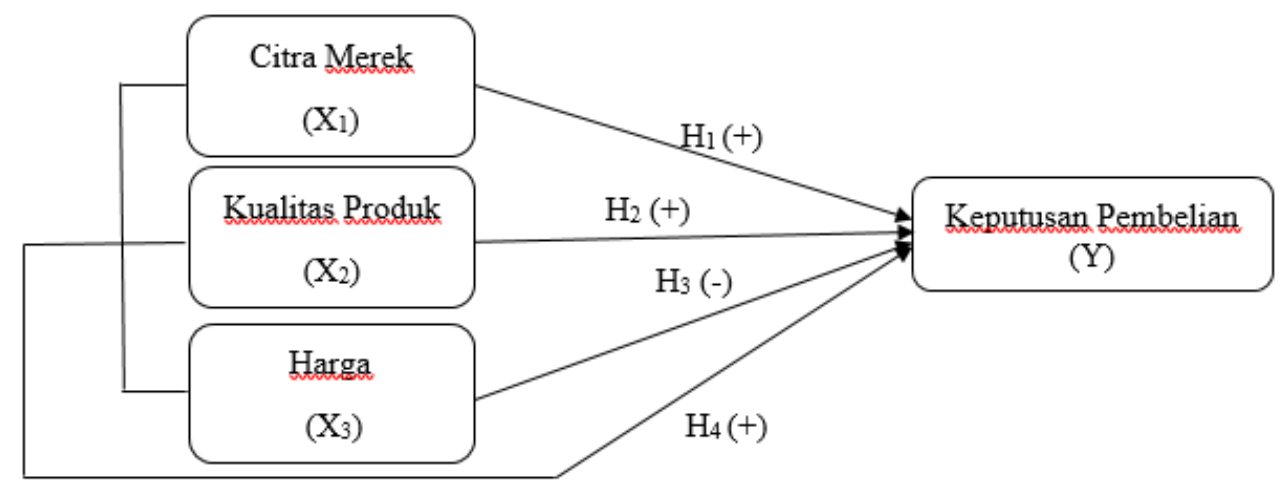

\section{Gambar 1. Kerangka Pikir}

Keterangan:

$\mathrm{X} 1=$ Citra Merek

$\mathrm{X} 2=$ Kualitas Produk

$\mathrm{X} 3=$ Harga

$\mathrm{Y} \quad=$ Keputusan Pembelian

$\mathrm{H} 1=$ Pengaruh terhadap X1 terhadap $\mathrm{Y}$

$\mathrm{H} 2$ = Pengaruh $\mathrm{X} 2$ terhadap $\mathrm{Y}$

$\mathrm{H} 3=$ Pengaruh $\mathrm{X} 3$ terhadap $\mathrm{Y}$

$\mathrm{H} 4=$ pengaruh $\mathrm{X} 1, \mathrm{X} 2, \mathrm{X} 3$ terhadap $\mathrm{Y}$

\section{METODE PENELITIAN}

\section{Populasi dan sampel}

Populasi merupakan totalitas dari seluruh unsur yang ada dalam sebuah wilayah penelitian (Juliandi, 2013). Populasi dalam penelitian ini adalah mahasiswa aktif Universitas Mercu Buana Yogyakarta tahun ajaran 2018/2019, dengan total jumlah seluruh mahasiswa 8.717. Karena jumlah mahasiswa yang menjadi populasi jumlahnya relatif banyak maka dilakukan pengambilan sampel dalam penelitian ini.

Sampel adalah sebagian dari jumlah dan karakteristik yang dimiliki oleh populasi tersebut, ataupun bagian kecil dari anggota populasi yang diambil menurut prosedur tertentu sehingga dapat mewakili populasinya. Dalam penenlitian ini metode pengambilan sampel dilakukan dengan menggunakan teknik non probability sampling dengan cara purposive sampling yaitu pengambilan sampel dilakukan dengan pertimbangan sebagaian dari anggota populasi menjadi sampel penelitian. Sampel dalam penelitian ini adalah mahasiswa Universitas Mercu Buana Yogyakarta yang menggunakan produk merek Eiger. Pengambilan jumlah sampel menurut Slovin (2011), dapat menggunakan rumus: 
Devi Puspita Sari dan Audita Nuvriasari :Pengaruh Citra Merek, Kualitas Produk Dan Harga Terhadap Keputusan Pembelian Produk Merek Eiger(Kajian Pada Mahasiswa Universitas Mercu Buana Yogyakarta)

$$
\begin{aligned}
& n=\frac{n}{\left(1+N(e)^{2}\right)} \\
& n=\frac{8.717}{\left(1+8.717(0,1)^{2}\right)} \\
& n=98,86
\end{aligned}
$$

Keterangan:

n : Ukuran sampel

N : Ukuran Populasi

e $\quad$ : Kelonggaran ketidaktelitian karena pengambilan sample yang dapat ditolerir sebesar $10 \%$

Berdasarkan perhitungan diatas, maka jumlah sampel yang digunakan adalah 98,86 responden, dan dibulatkan menjadi 100 responden. Jadi jumlah sampel yang dipakai dalam penelitian ini berjumlah 100 responden yang merupakan bagian dari populasi yang mengacu pada mahasiswa Universitas Mercu Buana Yogyakarta yang menggunakan produk merek Eiger.

\section{Jenis dan Sumber Data}

Menurut Rumengan (2013), ketika melakukan tahap statistik adanya suatu pengumpulan suatu data yang akan diolah, pada umumnya statistik memiliki dua jenis data yaitu data primer dan data sekunder. Sumber data penelitian meliputi yaitu data primer adalah merupakan data yang dikumpulkan secara langsung oleh peneliti dengan cara memberikan pernyataan secara tertulis terhadap responden dalam bentuk kuesioner. Kuesioner yang diberikan merupakan kuesioner terstruktur, yaitu jawaban dari daftar pernyataan telah disediakan dan responden diminta untuk memilih satu jawaban yang sesuai dengan dirinya, sehingga kuesioner dirancang secara tertutup. Sedangkan data sekunder adalah data yang diperoleh secara tidak langsung dalam penelitian atau dari pihak lain yang terkait dengan objek yang diteliti. Data ini bisa diperoleh dari studi pustaka berupa buku, referensi, dokumen, dan sebagainya yang berfungsi untuk melengkapi data primer.

\section{Teknik Pengumpulan Data}

Pengumpulan data ditentukan oleh variabel-variabel yang ada dalam hipotesis. Pengumpulan data dilakukan terhadap sampel yang telah ditentukan sebelumnya. Dalam penelitian ini menggunakan dua metode pengumpulan data yaitu, metode angket (kuesioner) merupakan teknik pengumpulan data yang dilakukan dengan cara memberi seperangkat pertanyaan tertulis kepada responden untuk dijawabnya, dapat diberikan secara langsung atau melalui pos atau internet. Sedangkan metode Wawancara Yaitu tanya jawab lisan antara dua orang atau lebih secara langsung berguna untuk mendapatkan data dari tangan pertama (primer), pelengkap teknik pengumpulan lainnya, menguji hasil pengumpulan data lainnya.

\section{Pengukuran Variabel Penelitian}

Penelitian yang dilakukan nantinya akan menggunakan alat bantu berupa kuesioner, yang mana jawaban-jawaban responden tersebut akan diukur dengan menggunakan skala Likert. Skala pengukuran untuk semua variabel yang meliputi citra merek, kualitas produk, harga dan keputusan pembelian menggunakan skala Likert 1-5 dengan keterangan skor 1 untuk jawaban Sangat Tidak Setuju (STS), skor 2 untuk jawaban Tidak Setuju (TS), skor 3 untuk jawaban Netral (CS), skor 4 untuk jawaban Setuju (S) dan skor 5 untuk jawaban Sangat Setuju (SS). 


\section{Metode Analisis Data}

Penelitian ini menggunakan dua metode analisis data yaitu analisis data kualitatif dan analisis data kuantitatif.Analisis data kualitatif menggunakan anlisis data deskriptif, alat statistik deskriptif yang digunakan dalam penelitian ini adalah mean arithmetic (rata-rata hitung) yang pengkategorian hasilnya berdasarkan pada rentang skala.Sedangkan analisis data kuantitatif pengukurannya menggunakan alat analisis yang berupa uji asumsi klasik, uji regresi linier berganda, uji korelasi berganda, uji determinasi dan uji hipotesis.

\section{HASIL DAN PEMBAHASAN}

\section{Hasil Penelitian}

\section{Uji Asumsi Klasik}

\section{Uji Normalitas}

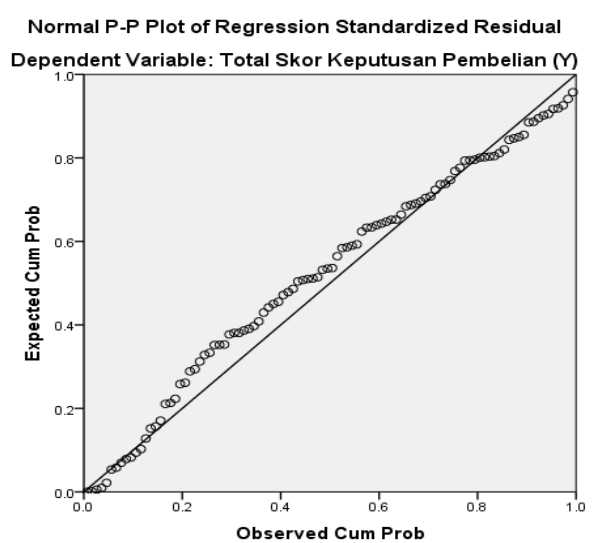

Gambar 2. Uji Normalitas

Berdasarkan gambar 2 dapat diketahui bahwa penyebaran data (titik) pada Normal $P$ Plot of Regression Standardized dari variabel terikat menyebar disekitar garis diagonal, maka model regresi memenuhi asumsi normalitas.

\section{Uji Multikolinieritas}

Tabel 1. Uji Multikolinieritas

\begin{tabular}{|c|c|c|}
\hline \multirow{2}{*}{ Model } & \multicolumn{2}{|c|}{ Collinearity Statistics } \\
\hline & Tolerance & VIF \\
\hline (Constant) & & \\
\hline Total Skor Citra Merek (X1) & .508 & 1.969 \\
\hline Total Skor Kualitas Produk (X2) & .413 & 2.422 \\
\hline Total Skor Harga (X3) & .638 & 1.568 \\
\hline
\end{tabular}

Berdasarkan tabel 1 dapat diketahui bahwa tidak terdapat multikolinieritas dalam model karena nilai tolerance diatas 0,1 dan VIF kurang dari 10. 
Devi Puspita Sari dan Audita Nuvriasari :Pengaruh Citra Merek, Kualitas Produk Dan Harga Terhadap Keputusan Pembelian Produk Merek Eiger(Kajian Pada Mahasiswa Universitas Mercu Buana Yogyakarta)

\section{Uji Heteroskedastisitas}

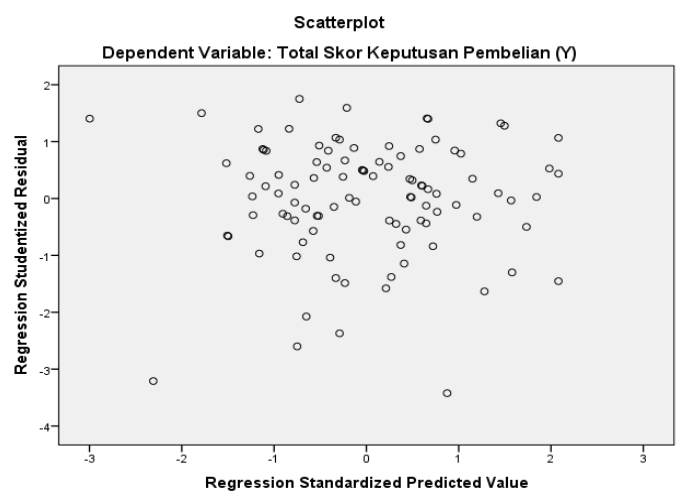

\section{Gambar 3. Uji Heteroskedastisitas}

Berdasarkan gambar 3 grafik scatter plot diketahui bahwa titik-titik menyebar secara acak diatas dan dibawah angka nol serta tidak membentuk pola khusus. Hal ini menunjukan bahwa tidak terjadi heteroskedastisitas yang berarti tidak terjadi ketidaksamaan varian dari residual satu pengamatan ke pengamatan lain dalam penelitian.

\section{Regresi Linier Berganda}

Tabel 2. Uji Regresi Linier Berganda

\begin{tabular}{lccccc}
\hline \multirow{2}{*}{ Model } & \multicolumn{2}{c}{$\begin{array}{c}\text { Unstandardized } \\
\text { Coefficients }\end{array}$} & $\begin{array}{c}\text { Standardized } \\
\text { Coefficients }\end{array}$ & \multirow{2}{*}{ t } & \multirow{2}{*}{ Sig. } \\
\cline { 2 - 4 } & $\mathbf{B}$ & Std. Error & Beta & & \\
\hline (Constant) & -2.328 & 3.230 & & -.721 & .473 \\
Total Skor Citra Merek $\left(\mathrm{X}_{1}\right)$ & .289 & .105 & .291 & 2.752 & .007 \\
Total Skor Kualitas Produk $\left(\mathrm{X}_{2}\right)$ & .319 & .124 & .302 & 2.578 & .011 \\
Total Skor Harga $\left(\mathrm{X}_{3}\right)$ & .409 & .205 & .189 & 1.999 & .048 \\
\hline
\end{tabular}

Berdasarkan hasil analisis diperoleh hasil regresi linier berganda:

$\mathrm{Y}=-2 \cdot 328+0,291 \cdot \mathrm{X} 1+0,302 \cdot \mathrm{X} 2+0,189 \cdot \mathrm{X} 3$

Dari hasil etiminasi regresi yang diperoleh dapat dijelaskan maka koefisien regresi sebagai berikut:

$\mathrm{a}=-2.328 \quad$ Menunjukan nilai konstanta dari keputusan pembelian yang berarti jika pengaruh citra merek, kualitas produk dan harga sama dengan nol maka nilai Keputusan Pembelian adalah sebesar -2.328.

$\beta 1=0,291 \quad$ Menunjukan nilai koefisien beta pada variabel citra merek sebesar 0,291 yang berarti apabila penilaian terhadap variabel citra merek $\left(\mathrm{X}_{1}\right)$ meningkat sebesar satu satuan maka penilaian terhadap variabel keputusan pembelian akan meningkat sebesar 0,291 satuan. Variabel citra merek $\left(\mathrm{X}_{1}\right)$ memiliki arah hubungan positif terhadap keputusan pembelian.

$\beta 2=0,302 \quad$ Menunjukan nilai koefisien beta pada variabel kualitas produk $\left(\mathrm{X}_{2}\right)$ sebesar 0,302 yang berarti apabila penilaian terhadap variabel kualitas produk $\left(\mathrm{X}_{2}\right)$ meningkat sebesar satu satuan maka penilaian terhadap variabel keputusan pembelian akan meningkat sebesar 0,302 satuan. Variabel kualitas produk $\left(\mathrm{X}_{2}\right)$ memiliki arah hubungan positif terhadap keputusan pembelian.

$\beta 3=0,189 \quad$ Menunjukan nilai koefisien beta pada variabel harga sebesar 0,189 yang berarti apabila penilaian terhadap variabel harga $\left(\mathrm{X}_{3}\right)$ meningkat sebesar satu satuan 
maka penilaian terhadap variabel keputusan pembelian akan meningkat sebesar 0,189 satuan. Variabel harga $\left(\mathrm{X}_{3}\right)$ memiliki arah hubungan positif terhadap keputusan pembelian.

Berdasarkan analisis diatas dapat diketahui bahwa besarnya koefisien beta, maka pengaruh paling dominan variabel bebas terhadap variabel terkait adalah pengaruh variabel Kualitas produk $\left(\mathrm{X}_{2}\right)$ karena koefisien betanya (Standardized Coefficients) paling besar dibandingkan yang lainnya yaitu 0,302 .

\section{Uji Koefisien Determinasi $\left(\mathbf{R}^{2}\right)$}

Tabel 3. Uji Koefisien Determinasi $\left(\mathbf{R}^{2}\right)$

\begin{tabular}{ccccc}
\hline Model & $\mathbf{R}$ & $\begin{array}{c}\mathbf{R} \\
\text { Square }\end{array}$ & $\begin{array}{c}\text { Adjusted } \\
\text { R Square }\end{array}$ & $\begin{array}{c}\text { Std. Error of } \\
\text { the Estimate }\end{array}$ \\
\cline { 2 - 5 } 1 & $.674^{\mathrm{a}}$ & .454 & .437 & 3.267 \\
\hline
\end{tabular}

Berdasarkan tabel 3 dapat dijelaskan analisis koefisien determinasi $\left(\mathrm{R}^{2}\right)$ bahawa nilai Adjusted R Square adalah sebesar 0,437 (43,7\%). Hal ini menunjukan bahwa keputusan pembelian pada produk merek Eiger dipengaruhi oleh variabel citra merek, kualitas produk dan harga sebesar 43,7\% sedangkan sisanya sebesar 56,3\% dipengaruhi oleh variabel lain yang tidak diteliti dalam penelitian ini seperti faktor budaya, sosial, pribadi dan psikologis.

\section{Uji Hipotesis}

Uji Parsial (uji t)

Tabel 4. Uji Parsial (uji t)

\begin{tabular}{lccccc}
\hline \multirow{2}{*}{ Model } & \multicolumn{2}{c}{$\begin{array}{c}\text { Unstandardized } \\
\text { Coefficients }\end{array}$} & $\begin{array}{c}\text { Standardid } \\
\text { Coefficients }\end{array}$ & \multirow{2}{*}{ t } & \multirow{2}{*}{ Sig. } \\
\cline { 2 - 5 } & $\mathbf{B}$ & Std. Error & Beta & & \\
\hline (Constant) & -2.328 & 3.230 & & -.721 & .473 \\
Total Skor Citra Merek (X1) & .289 & .105 & .291 & 2.752 & .007 \\
Total Skor Kualitas Produk (X2) & .319 & .124 & .302 & 2.578 & .011 \\
Total Skor Harga (X3) & .409 & .205 & .189 & 1.999 & .048 \\
\hline
\end{tabular}

Berdasarkan tabel 4 hasil pengujian secara parsial (Uji T) dapat dijelaskan hasil pengujian variabel citra merek $\left(\mathrm{X}_{1}\right)$ diperoleh nilai $\mathrm{t}_{\text {hitung }}=2,752$ dengan signifikasi sebesar $0,007<0,05$. Nilai $t_{\text {tabel }}$ dengan $d f=96$ diperoleh $t_{\text {tabel }}$ sebesar 1,98498. Dengan demikian $\mathrm{t}_{\text {hitung }}$ lebih besar dari $\mathrm{t}_{\text {tabel }}(2,752>1,98498)$ maka secara signifikan variabel citra merek $\left(\mathrm{X}_{1}\right)$ berpengaruh terhadap keputusan pembelian $(\mathrm{Y})$. Hasil pengujian variabel kualitas produk $\left(\mathrm{X}_{2}\right)$ diperoleh nilai $t_{\text {hitung }}=2,578$ dengan signifikasi sebesar $0,011<0,05$. Nilai $t_{\text {tabel }}$ dengan $\mathrm{df}=$ 96 diperoleh $t_{\text {tabel }}$ sebesar 1,98498. Dengan demikian $t_{\text {hitung }}$ lebih besar dari $t_{\text {tabel }}(2,578>$ 1,98498) maka secara signifikan variabel kualitas produk $\left(\mathrm{X}_{2}\right)$ berpengaruh terhadap keputusan pembelian (Y). Hasil pengujian variabel harga $\left(\mathrm{X}_{3}\right)$ diperoleh nilai $t_{\text {hitung }}=1,999$ dengan signifikasi sebesar $0,048<0,05$. Nilai $t_{\text {tabel }}$ dengan $\mathrm{df}=96$ diperoleh $\mathrm{t}_{\text {tabel }}$ sebesar 1,98498. Dengan demikian $t_{h i t u n g}$ lebih besar dari $t_{\text {tabel }}(1,999>1,98498)$ maka secara signifikan variabel harga $\left(\mathrm{X}_{3}\right)$ berpengaruh terhadap keputusan pembelian $(\mathrm{Y})$. 
Devi Puspita Sari dan Audita Nuvriasari :Pengaruh Citra Merek, Kualitas Produk Dan Harga Terhadap Keputusan Pembelian Produk Merek Eiger(Kajian Pada Mahasiswa Universitas Mercu Buana Yogyakarta)

\section{Uji Simultan (Uji F)}

Tabel 5.Hasil Pengujian Uji Simultan (UjiF)

\begin{tabular}{lccccc}
\hline Model & $\begin{array}{c}\text { Sum of } \\
\text { Squares }\end{array}$ & Df & $\begin{array}{c}\text { Mean } \\
\text { Square }\end{array}$ & F & Sig. \\
\hline Regression & 852.396 & 3 & 284.132 & 26.622 & $.000^{\mathrm{b}}$ \\
Residual & 1024.594 & 96 & 10.673 & & \\
Total & 1876.990 & 99 & & & \\
\hline
\end{tabular}

Berdasarkan hasil pengujian uji $\mathrm{F}$ yang disajikan pada tabel 4.19 diatas, dapat diketahui bahwa nilai $F_{\text {hitung }}=26,622$ dengan signifikasi sebesar 0,000. Nilai $F_{\text {tabel }} l$ dengan df1 $=3$ dan df2 $=96$ diperoleh hasil 2,70. Dengan demikian $F_{\text {hitung }}$ lebih besar dari $F_{\text {tabel }}(26,622>2,70)$ dan nilai signifikasi $0,000<0,05$, maka variabel citra merek $\left(\mathrm{X}_{1}\right)$, kualitas produk $\left(\mathrm{X}_{2}\right)$, dan harga $\left(\mathrm{X}_{3}\right)$ secara simultan atau bersama - sama berpengaruh terhadap Keputusan Pembelian (Y) pada produk merek Eiger.

\section{Pembahasan}

Penelitian ini bertujuan untuk mengetahui pengaruh citra merek, kualitas produk dan harga terhadap keputusan pembelian produk merek Eiger pada mahasiswa aktif Universitas Mercu Buana Yogyakarta.

\section{Pengaruh Citra Merek Terhadap Keputusan Pembelian Produk Merek Eiger.}

Penelitian ini menunjukan bahwa citra merek berpengaruh secara signifikan terhadap keputusan pembelian produk merek Eiger. Hal tersebut terbukti dengan nilai thitung sebesar 2,752 dan nilai probabilitas sebesar 0,007 dimana angka probabilitas tersebut signifikan karena $0,007<0,05$. Hal ini menunjukan bahwa citra merek yang baik mampu meningkatkan sikap konsumen dalam keputusan pembelian, dengan demikian penetapan merek yang baik akan menimbulkan citra merek yang kuat dibenak konsumen. Karena merek yang sudah melekat di hati konsumen merupakan asset yang paling berharga bagi perusahaan. Dengan mempertahankan keunggulan citra merek yang di miliki perusahaan, konsumen mampu menunjukkan perilaku yang loyal terhadap merek tersebut sehingga menimbulkan sikap puas akan merek tersebut dan juga berkomitmen terhadap merek tersebut.

\section{Pengaruh Kualitas Produk Terhadap Keputusan Pembelian Produk Merek Eiger.}

Penelitian ini menunjukan bahwa kualitas produk berpengaruh secara signifikan terhadap keputusan pembelian produk merek Eiger. Hal tersebut terbukti dengan nilai thitung sebesar 2,578 dan nilai probabilitas sebesar 0,011 dimana angka probabilitas tersebut signifikan karena $0,011<0,05$. Hal ini menunjukan bahwa kualitas produk yang baik mampu meningkatkan sikap konsumen dalam keputusan pembelian, kualitas dari sebuah produk merupakan salah satu pertimbangan penting konsumen dalam pengambilan keputusan pembelian.Memberikan kualitas produk yang tinggi merupakan kewajiban perusahaan untuk mengapai tujuannya.Kualitas produk yang baik membuat konsumen cenderung melakukan keputusan pembelian. Penjualan produk dengan kualitas yang bagus, orisinil, resmi akan meningkatkan kepercayaan konsumen dalam hal keandalan produk.

\section{Pengaruh Harga Terhadap Keputusan Pembelian Produk Merek Eiger.}

Penelitian ini menunjukan bahwa harga berpengaruh secara signifikan terhadap keputusan pembelian produk merek Eiger. Hal tersebut terbukti dengan nilai thitung sebesar 1,999 dan nilai probabilitas sebesar 0,048 dimana angka probabilitas tersebut signifikan karena $0,048<0,05$. Hal ini menunjukan bahwa harga merupakan salah satu penentu dalam mempengaruhi keputusan pembelian.Kesesuaian harga dengan kualitas produk harus 
seimbang agar produk-produk yang ditawarkan dapat diterima oleh konsumen dan mendorong pertimbangan konsumen untuk memutuskan melakukan pembelian.

\section{Pengaruh Citra Merek, Kualitas Produk dan Harga Terhadap Keputusan Pembelian Produk Merek Eiger.}

Penelitian ini menunjukan bahwa citra merek, kualitas produk dan harga berpengaruh secara signifikan terhadap keputusan pembelian produk merek Eiger. Hal tersebut terbukti dengan nilai Fhitung sebesar 26,622 dan nilai probabilitas sebesar 0,000 dimana angka probabilitas tersebut signifikan karena $0,000<0,05$.

\section{SIMPULAN}

Berdasarkan analisis data yang dilakukan peneliti terhadap variabel-variabel tentang pengaruh citra merek, kualitas produk dan harga terhadap keputusan pembelian produk merek Eiger pada mahasiswa Universitas Mercu Buana Yogyakarta maka dapat disimpulkan bahwa:

1. Citra merek berpengaruh positif dan signifikan terhadap keputusan pembelian produk merek Eiger.

2. Kualitas produk berpengaruh positif dan signifikan terhadap keputusan pembelian produk merek Eiger.

3. Harga berpengaruh positif dan signifikan terhadap keputusan pembelian produk merek Eiger.

4. Citra merek, kualitas produk dan harga secara simultan berpengaruh positif dan signifikan terhadap keputusan pembelian produk merek Eiger.

5. Variabel yang paling dominan berpengaruh terhadap keputusan pembelian produk merek Eiger adalah kualitas produk

\section{DAFTAR PUSTAKA}

Abdulah, R. R., Yulianto, E., Mawardi , M. K. 2017. Pengaruh Sikap, Faktor Pribadi, dan Faktor Sosial Terhadap Keputusan Pembelian (Survay pada Konsumen Kartu perdana SimPATI di GraPARI Malang). Jurnal Administrasi Bisnis (JAB).42(1).

Achidah, N., Warso , M. M., Hasiolan, L. B. 2016. Pengaruh Promosi, Harga dan Desain Terhadap Keputusan Pembelian Sepeda Motor Mio GT (Study Empiris pada produk Yamaha Mio GT di Weleri-Kendal). Journal Of Management.2(2).

Amalia, S., \& Asmara Nst, M. O. 2017. Pengaruh Citra Merek, Harga dan Kualitas Produk Terhadap Keputusan Pembelian Handphone Merek Xiaomi di Kota Langsa. Jurnal Manajemen dan Keuangan.6(1).

Buyung, S., Manday, S. L., B Sumarauw, J. S. 2016. Pengaruh Citra Merek, Kualitas Produk dan Hrga Terhadap Keputusan Pembelian Produk semen Tiga Roda di Toko Lico. Jurnal Berkala Ilmiah Efisiensi.16(04).

Daud, D. 2013. Promosi dan Kualitas Layanan Pengaruhnya Terhadap Keputusan Konsumen Menggunakan Jasa Pembiayaan Pada PT. Bess Finance Manado. Jurnal Riset Ekonomi, Manajemen, Bisnis dan Akuntansi ISSN.1(4): 2303-1174.

Defriansyah, D., Daud, I., \& Nailis, W. (2016). Pengaruh Citra Merek, Harga dan Kualitas Produk Terhadap Keputusan pembelian Smartphone Samsung (Studi Kasus Mahasiswa Universitas Sriwijaya Indralaya). Jurnal Ilmiah Manajemen Bisnis dan Terapan Tahun Xlll. 2.

Gifani, A., \& Syahputra. 2017. Pengaruh Citra Merek Terhadap Keputusan Pembelian Produk Smartphone Oppo pada Mahasiswa Universitas Telkom. Jurnal Bisnis dan Iptek ISSN.10(2): 2502-1559.

Halomoan Samosir, C. B., Prayoga K, A. B. 2015. Jurnal Pengaruh Persepsi Harga dan Promosi Terhadap Keputusan Pembelian Produk Enervon-C. Jurnal Ilmiah Manajemen dan Bisnis. 1(3). 
Devi Puspita Sari dan Audita Nuvriasari :Pengaruh Citra Merek, Kualitas Produk Dan Harga Terhadap Keputusan Pembelian Produk Merek Eiger(Kajian Pada Mahasiswa Universitas Mercu Buana Yogyakarta)

Mamahir, P., Soegoto, A. S., Tumbuan, W. A. 2015. Pengaruh Brand Image, Brand Trust, dan Kualitas Produk Terhadap Keputusan Pembelian Mobil Toyota New Yaris pada PT. Hasjrat Abadi Manado. Jurnal berkala Ilmia Efisiensi. 15(5).

Sembiring, I. J., Suharyono, Kusumawati , A. 2014. Pengaruh Kualitas Produk dan Kualitas Pelayanan Terhadap Kepuasan Pelanggan dalam Membentuk Loyalitas Pelanggan (Studi pada Pelanggan McDonald's MT.Haryono Malang. Jurnal Administrasi Bisnis (JAB). 15 (1).

Supriyono, K., Hasiolan, L. B., Warso, M. M. 2014. Pengaruh Produk, Harga dan Promosi Terhadap Keputusan Konsumen dalam Membeli Rumah pada Perumahan Bukit Semarang Baru (BSB) City di Semarang. Jurnal Skripsi Ekonomi Manajemen.

Vanessa, I., \& Arifin, Z. 2017. Pengaruh Citra Merek (Brand Image) dan Harga Terhadap Keputusan Pembelian Konsumen (Survei pada Mahasiswa Program Studi Administrasi Bisnis Fakultas Ilmu Administrasi Universitas Brawijaya Malang Tahun Angkatan 2013/2014 dan 2014/2015 Pengguna Kartu Pra-Bayar Simpati. rnal Administrasi Bisnis (JAB). 51(1).

Windarti , T., \& Ibrahim, M. 2017. Pengaruh Kualitas Produk dan Kualitas Pelayanan Terhadap Kepuasan Konsumen Produk Donat Madu (Studi pada Konsumen CV. Donat Madu Cihanjuang-Pekanbaru). Jom FISIP. 4(2). 